\author{
A.R. Yeshkeyev \\ Ye.A. Buketov Karaganda State University, Kazakhstan \\ (E-mail: modth1705@mail.ru)
}

\title{
The properties of central types with respect to enrichment by Jonsson set
}

\begin{abstract}
The main results of the article are for a new class of theories, namely existential prime strongly convex Jonsson theories. This class is quite broad in terms of algebra, for example it includes the class of all Abelian groups and groups. This article examines the issues relating to the following subjects. The language on considered a signature adds a new predicate symbol which reflects the presence of the Jonsson set. The concept of Jonsson sets in Jonsson theory is a generalization of the concept of the dimension of the linear space. T.G. Mustafin in due time, introduced and proved the basic properties of the syntactic and semantic similarity. In this paper, in the extended language we have similare to the results for the considered theories. In this direction, the main results of the work are the following results: The coincidence of $P$-stability for the prototype and its central-type center. The equivalence of syntactic similarity of existentially EPSCJ compleate theories and syntactical similarity of their centers was consedered. From this it can be seen a lot of useful facts. In particular semantic similarity. As well as a list of semantic properties, which are stored at the semantic similarity. For example, the semantic properties that invariant properties of the first order applies Morley rank of the central type.
\end{abstract}

Keywords: Jonsson theory, Jonsson set, fragment of Jonsson sets, Existentially Prime Strongy Convex Jonsson theories.

This work is associated with the concepts of convex theory in the class of existentially prime Jonsson theories. We denote such theories as ExistentiallyPrimeStrongyConvexJonsson(EPSCJ).

In [1] was defined the class of $\Delta-P J$ theories. Such theories are generalized the concept of Jonson's theories. In this paper we investigate the corresponding concept in which the notion of $P-\lambda$-stable (in sense [2]) and the notion of syntactical similar in sense [3] are replaced in some equivalent style in the class of $\exists$-complete perfect EPSCJ theories. Moreover we are considered some enrichment of signatures of such theories and we defined and considered the concept of central types of ones. This generalization led us to different questions of note of stability in enrich signature, for example like in [2]. And finally we can to conclude that it is appropriate to consider and to investigate the EPSCJ - analogues of some properties and notions from classical model theory in frames of EPSCJ - theories.

Let $L$ be a countable first-order language.

Definition 1. The inductive theory $T$ called existential prime, if:

1. It has a algebraicslly prime model and the class of all algebraically prime models it is denoted by $A P_{T}$.

2. The class $\left(E_{T}\right)$ of model theory $T$ has nonempty intersection with an $A P$ class, ie, $T_{A P} \cap E_{T} \neq \emptyset$.

It is well known [1] that if Jonsson Theories $T$ is perfect, then the class of its existentially closed models $E_{T}$ is elementary and coincides with the $M o d T^{*}$, where $T^{*}$ its center. Otherwise, i.e. if the theory $T$ is not perfect, instead of $\operatorname{ModT}$ we are working with the class $E_{T}$, ie, it is assumed that all the allegations relate only existentially closed models. Also, we assume in the case of an imperfect, that besides the existential closure of all these models is algebraically prime.

We say that all $\forall \exists$ - corollary of the arbitrary theory form a Jonsson fragment of this theory, if the deductive closure of these $\forall \exists$ - corollary is Jonsson Theories. Obtained in this case Jonsson theories will be called Jonsson fragment (further fragment). Accordingly, it is determined by the fragment of Jonsson set. In both cases, we can carry out research Jonsson fragments on the connection with an initial theory that the new formulation of the problem research is Jonsson's theory.

Let $X$ Jonsson set in the theory $T$ and $M$ is existentially closed submodel of semantic model $C$, considered Jonsson theory $T$ where $d c l(X)=M$. Then let $\operatorname{Th} h_{\forall}(M)=\operatorname{Fr}(X), \operatorname{Fr}(X)$ is Jonsson fragment of Johnson sets $X$.

Definition 2. The theory $T$ is called convex if for any model $\mathfrak{U}$ and any family $\left\{\mathfrak{B}_{i} \mid i \in I\right\}$ of its substructures, which are models of the theory $T$, the intersection $\bigcap_{i \in I} \mathfrak{B}_{i}$ is a model theory $T$. It is assumed that this intersection is not empty. If this intersection is never empty, then the theory is called the strongly convex. 
We give the necessary definitions related to Jonsson theories in the enriched signature.

Let $T$ is an arbitrary Jonsson theory in the language of the first order signature $\sigma$. Let $C$ is a semantic model of theory $T$. Let $A \subseteq C$ is a Jonsson set of theory $T$. Let $\sigma_{\Gamma}(A)=\sigma \cup\left\{c_{a} \mid a \in A\right\} \cup \Gamma, \Gamma=\{P\} \cup\{c\}$.

Let $T_{A}^{C}=T \cup T h_{\forall \exists}(C, a)_{a \in A} \cup\left\{P\left(c_{a}\right) \mid a \in A\right\} \cup\{P(c)\} \cup\left\{{ }^{\prime \prime} P \subseteq^{\prime \prime}\right\}$ where $\left\{{ }^{\prime \prime} P \subseteq^{\prime \prime}\right\}$ is an infinite set of sentences expressing the fact that the interpretation of symbol $P$ is existentially closed submodel in the language of the signatures $\sigma_{\Gamma}(A)$ and this model is a definable closure of the set $A$. It is understood that the consideration the set of sentences is Jonsson theory and this theory generally is not complete.

Let $T^{*}$ is the center of the Jonsson theory $T_{A}^{C}$ and $T^{*}=T h\left(C^{\prime}\right)$ where $C^{\prime}$ is a semantic model of the theory $T_{A}^{C}$. By restriction theory $T_{A}^{C}$ to signatures $\sigma_{\Gamma}(A) \backslash\{c\}$ the theory $T_{A}^{C}$ becomes a complete type. This type we call a central type of the theory $T$ relatively the Jonsson set $A$ and denoted by $P_{A}^{C}$.

Let $T$ is an arbitrary EPSCJ theory in first order signature $\sigma$. Let $C$ is a semantic model of $T$. $A \subseteq C$. The requirement of existential closeness for a submodel is essential in that sense, that it should not be finite . The theory $T_{A}^{C}$ is not necessary complete. Through $S_{\Gamma}^{A}$ denote a set of all $\exists-$ completions of theory $T_{A}^{C}$. Let $\lambda$ is an arbitrary cardinal.

The EPSCJ theory is $J-P-\lambda$-stable, if $\left|S_{\Gamma}^{A}\right| \leq \lambda$ for any subset $A$ of $C$, such that $|A| \leq \lambda$.

Lemma. If $\operatorname{Fr}(X)=\operatorname{Fr}(A)$ is perfect $E P S C J$ theory, then $T_{A}^{C}$ is perfect $E P S C J$ theory.

Proof. First of all we need to note that adding the symbols of constants and one-placed predicate $P$ does not spoiled of EPSCJ-ness of $T$ and $T^{*}$. The proof of this ones standart cheking of definition of EPSCJ-ness. For proof of perfection of $T_{A}^{C}$ it is enough to show, that $T_{A}^{C}$ has the semantic model which will be saturated in its power.It is follows by definition $T_{A}^{C}$. As the given model we take semantic model $C$ of the theory $T$, and in depending on a subset $A$ and interpretation one-placed predicate $P$ in $C$ is the model $D=(C, M, a)_{a \in A}$ ,where $M$ is existentially closed submodel of $C$. It is easy to see that $D$ will be saturated in its power, since $C$ is existentially closed model itself, as semantic model of $T$.

Theorem 1. Let $T$ be a $\exists$-complete perfect $E P S C J$ theory $\operatorname{Fr}(A)$. Then the following conditions equivalent:

1) theory $T_{A}^{C}$ is $P-\lambda$-stable (in sense [2]);

2) theory $T^{*}$ is $J-P-\lambda$-stable.

Proof. We can now show that from 1) to 2) the proof is trivial, since if it is no more all completions than $\lambda$, then in particularly $\exists$-completions no more than $\lambda$. Let's prove from 2) in 1). Let the theory $T^{*}-J-P$-stable. It is equivalent to that, that $T_{A}^{C}$ in the signature $\sigma_{\Gamma}(A)=\sigma \cup\left\{c_{a} \mid a \in A\right\} \cup \Gamma$ is equivalent correspondingly to the positive Kaiser's hull $T^{0}$ of the theory $T$. By perfection of theory $T$ we have that $T^{0}=T^{*}$ and hence $T_{A}^{C}$ will be perfect EPSCJ theory. Let the theory $T^{0}$ has no more, than $\lambda \exists$-completions. The centre of the theory $T$ in the new signature will be equaled $T h(C, a)_{a \in A} \cup\left\{P\left(c_{a}\right) \mid a \in A\right\} \cup\left\{{ }^{\prime \prime} P \preceq^{\prime \prime}\right\} \cup\{P(c)\}$. Clear that $T^{*}=T^{C}$. We should be shown, that $T^{*}$ has no more then $\lambda$ completions. That means that $T^{*}$ will be $P-\lambda$ - stable. Let's understand due to what $T^{*}$ it is not complete in the new signature. Addition of constants gives only inessential expansions that will not change quantity types of existentially closed submodels $C$. The essential role is played the realizations of a predicate $P$. In this case realization of a predicate $P$ will be some elementary submodel $M$ of the model $C$. As $C$ is the semantic model of $T$, this one is existentially closed and by sense of a predicate $P$ in $C(M \prec C)$ follows, that $M \in E_{T}$. Let's consider any completion $T^{\prime}$ theories $T^{*}$ in the new signature. By definition $T^{*}$ there exist such model $M$ from $E_{T}$, such that $T^{\prime}=T h(C, M, a)_{a \in A}$, where $M$ - interpretation of a predicate $P$ in semantic model $C . T^{\prime}=T h(C, M, a)_{a \in A}$ is $E P S C J$ theory. In this case $T^{\prime}$ is it positive model complete theory. And we have by positive model completeness $T^{\prime}$ that any formula in is equivalent to some positive existential formula in $T^{\prime}$. Then by $\exists$-completeness of the theory $T$ such completions by above mentioned are no more than $\lambda$. So, the statement is proved.

Let $T$ is arbitrary EPSCJ theory, then $E(T)=\bigcup_{n<\omega} E_{n}(T)$, where $E_{n}(T)$ is the lattice of positive existential formulas with exactly $n$ free variables.

Let $T_{1}$ and $T_{2}$ are $E P S C J$ theories.

We shall say that, $T_{1}$ and are EPSCJ syntactically similar, if and only if there exist a bijection $f: E\left(T_{1}\right) \rightarrow$ $\rightarrow E\left(T_{2}\right)$ such that:

1) the restriction of $f$ up $E_{n}\left(T_{1}\right)$ is isomorphism of the $E_{n}\left(T_{1}\right)$ and $E_{n}\left(T_{2}\right), n<\omega$;

2) $f\left(\exists v_{n+1} \varphi\right)=\exists v_{n+1} f(\varphi), \varphi \in E_{n}(T), n<\omega$;

3) $f\left(v_{1}=v_{2}\right)=\left(v_{1}=v_{2}\right)$. 
Theorem 2. Let $T_{1}$ and $T_{2}$ are $\exists-$ complete perfect EPSCJ theories. Then the following conditions equivalent:

1) $T_{1}^{*}$ and $T_{2}^{*}$ are $J$ - syntactically similar in sense [4].

2) $T_{1}^{C}$ and $T_{2}^{C}$ are syntactical similar in sense [3].

Proof. We can now show from 1) to 2).We have that for any $n<\omega E_{n}\left(T_{1}\right)$ is isomorphic to $E_{n}\left(T_{2}\right)$. Let this isomorphism is making by $f_{1 n}$. Under conditions of theorem and perfection for any $n<\omega E_{n}\left(T_{1}\right)$ and $E_{n}\left(T_{2}\right)$ are Boolean algebras. But with perfection of $T_{1}$ and $T_{2}$ we have that $T_{1}^{*}$ and $T_{2}^{*}$ are positive model complete and so for any $n<\omega, \varphi(\bar{x}) \in F_{n}\left(T_{1}^{*}\right)$ there exist $\psi(\bar{x})$ from $E_{n}\left(T_{1}^{*}\right)$ that in $T_{1}^{*}=\varphi \leftrightarrow \psi$. And in power of $T_{1}$ is complete for positive existential sentences and $E_{n}\left(T_{1}\right) \subseteq E_{n}\left(T_{1}^{*}\right)$ (in power of $T_{1} \subseteq T_{1}^{*}$ ), we have that $E_{n}\left(T_{1}\right)=E_{n}\left(T_{1}^{*}\right)$. With the same argument we have that $E_{n}\left(T_{2}\right)=E_{n}\left(T_{2}^{*}\right)$. For any $n<\omega, \varphi(\bar{x}) \in F_{n}\left(T_{1}^{*}\right)$ we are defining the following map between $F_{n}\left(T_{1}^{*}\right.$ and $F_{n}\left(T_{2}^{*}\right.$ by next way $f_{2 n}\left(\varphi_{1}(\bar{x})\right)=f_{1 n}\left(\psi_{1}(\bar{x})\right)$, where in $T_{1}^{*}=\psi_{1} \leftrightarrow \varphi_{1}$, for $\psi_{1} \in E_{n}\left(T_{1}\right)$.It is easy to note that under properties of $f_{1 n}$ and above mentioned $f_{2 n}$ is a bijection which giving to us isomorphism between $F_{n}\left(T_{1}^{*}\right)$ and $F_{n}\left(T_{2}^{*}\right)$. Hence, $T_{1}^{*}$ and $T_{2}^{*}$ - syntactically similar in sense [3]. But from previously theorem 1 under consideration of central types of EPSCJ theory, since $T^{*}=T^{C}$, we have that 1$) \Rightarrow 2$ ) of theorem 2 is proved.

$2) \Rightarrow 1$ ). It is trivial, since $F_{n}\left(T_{1}^{*}\right)$ is isomorphic to $F_{n}\left(T_{2}^{*}\right)$ for any $n<\omega$,and in power of conditions of theorem this isomorphism is be able to go on to all subalgebras.

The following definitions led us to other kind of similarity, this one weaker than syntactical similarity. All definitions are taken from [3].

(1) By a pure triple we mean $\langle A, \Gamma, M\rangle$, where $M$ is not empty set, $\Gamma$ is a permutation group on $A$, and $M$ is a family of subsets of $A$ such that $M \in M \Rightarrow g(M) \in M$. For every $g \in \Gamma$.

(2) If $\left\langle A_{1}, \Gamma_{1}, M_{1}\right\rangle$ and $\left\langle A_{2}, \Gamma_{2}, M_{2}\right\rangle$ are pure triples, and $\psi: A_{1} \rightarrow A 2$ is a bijection, then $\psi$ is an isomorphism, if:

(i) $\Gamma_{2}=\left\{\psi g \psi^{-1}: g \in \Gamma_{1}\right\}$;

(ii) $M_{2}=\left\{\psi(E): E \in M_{1}\right\}$.

The pure triple $\langle|C|, G, N\rangle$ is called the semantically triple of $T$ (abbreviated s.t.), where $|C|$ is the universe of $C, G=\operatorname{Aut}(C)$ and $N$ is the class of all subsets of $|C|$ which are universes of suitable elementary submodels of $C$.

Complete theories $T_{1}$ and $T_{2}$ are semantically similar is and only if their semantic triples are isomorphic.

Very interesting one can to consider this result with the following:

Proposition 1 [3]. If $T_{1}$ and $T_{2}$ are syntactically similar, then $T_{1}$ and $T_{2}$ are semantically similar.

A property (or a notion) of theories (or models, or elements of models) is called semantic if and if it is invariant relative to semantic similarity.

It is turned out that a lot important notion from classical model theory belongs to next list.

Proposition 2 [3]. The following properties and notions are semantic:

(1) type;

(2) forking;

(3) $\lambda$-stability;

(4) Lascar rank;

(5) Strong type;

(6) Morley sequence;

(7) Orthogonality, regularity of types;

(8) $I\left(\aleph_{\alpha}, T\right)$ - the spectrum function.

By virtue of this notice we can say that all above mentioned properties and notions from Proposition 2 in the class of centers of $\exists$-complete perfect EPSCJ theories are semantic. Moreover if we are consider above mentioned enrichments of signatures of such theories and we will consider central types of ones we got that the situation will not change. And finally it is appropriate to consider the EPSCJ analogues of the list of semantic properties and notions from classical model theory. All unknown notions and results which we used in this article one can find out in [1-6].

\section{References}

1 Ешкеев А.Р. Категоричные позитивные теории // Синтаксис и семантика логических систем: материалы рос. шк.-семин., посвящ. 100-летию со дня рождения Курт Гедель. 23-27 августа 2006 г. Иркутск: Ин-т математики СО РАН; Изд-во гос. пед. ун-та, 2006. - С. 28-32. 
2 Мустафин Т.Г., Нурмагамбетов Т.А. О Р-стабильности полных теорий // Структурные свойства алгебраических систем: сб. науч. тр. - Караганда: Изд-во КарГУ, 1990. - С. 88-100.

3 Mustafin T.G. On similarities of complete theories // Logic Colloquium '90: proceedings of the Annual European Summer Meeting of the Association for Symbolic Logic, Held in Helsinki, Finland, July, 15-22, - 1990. - P. 259-265.

4 Ешкеев А.Р. О подобии в рј-теориях // Вестн. КазНПУ. - 2007. - № 4(20). - С. 113-117.

5 Eшкеев A.P., Касыметова М.Т. Йонсоновские теории и их классы моделей. - Караганда: Изд-во КарГУ, 2016. - C. 346.

6 Yeshkeyev A.R. Properties of central type for fragments of Jonsson sets // Bull. of Symbolic Logic. 2016. - Vol. 22. - No. 3. - P. 429, 430.

\title{
А.Р. Ешкеев \\ Йонсондық жиынның байытылуына қатысты орталық типтердің қасиеттері
}

\begin{abstract}
Мақаладағы негізгі нәтижелер жаңа теориялар класы үшін қарастырылды, яғни экзистенционалды жай қатты йонсондық дөңес теориялар үшін зерттелді. Берілген класс алгебра бойынша жеткілікті түрде кең болады, мысалы, оған барлық абельдік группалар және жай группалар класы жатады. Қарастырып отырған сигнатураның тілінде жаңа предикаттық символ қосылғанда, ол йонсондық жиынның бар болуын көрсетеді. Өз кезегінде модельде осындай жиынның бар болуы элементтердің өлшемі, коэффициенттері және ішкі жиындар үшін негіз болып табылады, яғни йонсондық теорияның йонсондық жиыны сызықтық кеңістіктің өлшемділік ұғымының жалпылауы орын алады. Өз уақытында Т.Ғ. Мұстафин синтаксистік және семантикалық ұқсастықтардың негізгі қасиеттерін енгізді және дәлелдеді. Бұл мақалада кеңейтілген тілде қарастырылып отырған теориялар үшін ұқсас нәтижелер берілген. Осы бағытта жұмыстың негізгі нәтижелері болып келесілер табылады. Центрлі тип және оның центрі үшін $p$-стабильділіктің сәйкестігі. Экзистенционалды жай кемел $E P S C J$ теориялардың синтаксистік ұқсастығы және олардың орталықтарының синтаксистік ұқсастығы бірбіріне пара-пар. Осыдан көптеген маңызды деректерді байқауға болады, мәселен, дербес жағдайда семантикалық ұқсастық. Сонымен қатар семантикалық ұқсастықты сақтайтын семантикалық қасиеттердің тізімі келтірілген. Мысалы, семантикалық қасиетке, яғни бірінші ретті инвариантты қасиетке, орталық типтердің Морли рангін жатқызуға негізі бар.
\end{abstract}

Kiлm сөздер: йонсондық теория, теориялар класы, йонсондық дөңес теориялар, йонсондық жиын, синтаксистік ұқсастық, орталық типтердің қасиеттері.

\section{A.P. Ешкеев}

\section{Свойства центральных типов относительно обогащения йонсоновским множеством}

\begin{abstract}
Основные результаты данной работы приведены для нового класса теорий, а именно для экзистенциально простых сильно йонсоновских выпуклых теорий. Данный класс является достаточно широким с точки зрения алгебры, к примеру, в него входит класс всех абелевых групп и просто групп. Автором рассмотрены вопросы, касающиеся следующей тематики. В язык рассматриваемой сигнатуры добавляется новый предикатный символ, который отражает наличие йонсоновского множества. В свою очередь, наличие такого множества в модели дает основание для размерностных соотношений элементов и подмножеств, так как понятие йонсоновского множества в йонсоновской теории есть обобщение понятия размерности в линейном пространстве. Т.Г.Мустафин в свое время ввел и доказал основные свойства синтаксического и семантического подобия. В статье в расширенном виде приведены аналогичные результаты для рассматриваемых теорий. В этом направлении основными являются следующие результаты: совпадение $p$-стабильности для прототипа центрального типа и его центра,
\end{abstract}


эквивалентность синтаксического подобия экзистенциально полных совершенных $E P S C J$-теорий и синтаксического подобия их центров. Из этого вытекает много полезных фактов, в частности, семантическое подобие. Кроме того, автором приведен список семантических свойств, которые сохраняются при семантическом подобии. Например, к семантическим свойствам, т.е. инвариантным свойствам первого порядка, относится и ранг Морли центральных типов.

Ключевые слова: йонсоновская теория, теория классов, йонсоновские выпуклые теории, йонсоновское множество, синтаксическое подобие, свойства центральных типов.

\section{References}

1 Yeshkeyev A.R. Syntax and semantics of logical systems: Materials of the Russian school-seminar, Dedicated to the 100th anniversary of the birth of Kent Gedel. Avgust, 23-27, 2006, Irkustk, Institut matematiki SO RAN. Publ. state pedagogical university, 2006, p. 28-32.

2 Mustafin T.G., Nurmagambetov T.A. Structural properties of algebraic systems, Karaganda: Published of KSU, 1990, p. 88-100.

3 Mustafin T.G. Logic Colloquium '90: proceedings of the Annual European Summer Meeting of the Association for Symbolic Logic, held in Helsinki, Finland, July, 15-22, 1990, p. 259-265.

4 Yeshkeyev A.R. Bulletin KazNPU, 4(20), 2007, p. 113-117.

5 Yeshkeev A.R., Kasymetova M.T. Jonsson theory and its classes of models, Karaganda: Published of KSU, 2016, p. 346.

6 Yeshkeyev A.R. Bulletin of Symbolic Logic, 2016, 22, 3, p. 429, 430. 